Оригинални научни рад

УДК 821.163.4(497.6).09-2

Примљен: 31. августа 2020.

Прихваћен: 2. марта 2021.

https://doi.org/10.46630/phm.13.2021.24

Раде Г. Симовић ${ }^{5}$

Универзитет у Источном Сарајеву

Филозофски факултет

\title{
САВРЕМЕНА И НОВА ДРАМА РЕПУБЛИКЕ СРПСКЕ
}

Намјера је нашег рада да у току све присутнијег раздвајања умјетничког стваралаштва Босне и Херцеговине, назначимо могуће правце и моделе типолошког развоја драмског стваралаштва у Републици Српској. Ради се о активној посљедици актуелних настојања да се, по сваку цијену, разграничи бошњачка, хрватска и српска књижевност постдејтонске Босне и Херцеговине која се, у каузално-посљедичном уланчавању, посредно преноси на социјалистичку, монархистичку, аустроугарску, османску и средњовјековну Босну и/или Херцеговину. До сада се о овом проблему углавном расправљало са позиције културно-историјског насљеђа, умјетничке прозе и поезије, док је драмско стваралаштво спорадично дотицано и недовољно истражено.

Кључне ријечи: српска драма, контекст, драматуршка композиција, мелодрама, историјска драма, постдрамско позориште

1.

Српску драму у Босни и Херцеговини су конституисали Светозар Ћоровић и Петар Кочић. Најдубљи траг оставио је Петар Кочић и његова драмска актовка Јазаваи, пред судом (позоришна праизведба у Београду, 1905). На тој стајној тачки у години настанка (1900) она умрежава и помирује европску актуелност народне драме и традицију српског народног глумована.

Кочићевску драмску парадигму, на идејном и конструкционом плану, опонашаће цијела једна генерација српских међуратних драматичара а њен европски ниво до краја је изведен у драмама Боривоја Јевтића.

Драме српских аутора, мотивски усмјерене на борбу против завојевача, чине усамљеничку грану босанско-херцеговачке драматургије која се, у другој половини двадесетог вијека, тематски суши и драматуршки сужава на немогућност комуникације и одсуство егзистенције (Жалица, Кољевић, Стојановић). Означена драматуршка парадигма једино

5 radesimovic@yahoo.com 
је сачувана и продужена у драмском стваралаштву Републике Српске, коју смо, у нашој Антологији штампаној 2011. године, именовали двосмисленим насловом - Драма Републике Српске (SIMOVIĆ 2011).

Драма Републике Српске уједно је поднасловљена као један могу$\hbar u$ поглед на савремену драму, препознатљив и видљив у драмском стваралаштву Јована Спрема (Ноћ пуног мјесеца), Бранка Брђанина Бајовића (Пада киша... јагодо, Бан Први...), Ненада Тадића (Шехити у Душановом царству), Рада Симовића (Хамлет у Рајској долини Српске) и Радмиле Смиљанић (Балон од камена).

На самом крају прошлог вијека заживио је одсјек драматургије на Академији сценских умјетности у Бањој Луци, покренут је Часопис за позориште и визуелне умјетности „Агон“Народног позоришта Републике Српске и Академије умјетности, а Народно позориште, наш национални театар, већ седам година објављује Конкурс за оригиналну савремену драму. Тај и такав приступ даљем развоју драмског и позоришног стваралаштва Републике Српске афирмисао је десетак драматичара млађе генерације гдје посебно издвајамо Радмилу Смиљанић, Тању Шљивар, Марија Ћулума и Јелену Којовић Тепић. Ми смо и у овом тексту зацртали једну врсту „продужене“ антологије уважавајући наведену парадигму савремене драме и хронолошки поредак праизведби позоришних извођења нових драма. Тиме смо објединили савремену и нову драму Републике Српске „кодирајући“ двије драме из претходне антологије као дио континуитета и везивно ткиво драмског стваралаштва Републике Српске у Босни и Херцеговини. Збирно гледајући, наш обједињени избор представља репрезентативни пресјек драмског стваралаштва у Републици Српској и поуздано свједочанство његовог настанка, израстања и развијања.

Позоришно стваралаштво Бање Луке и Републике Српске обиљежиле су, метафорично и суштински, три промјене имена Народног позоришта (Народно позориште Босанске Крајине до 1992, Крајишко народно позориште до 1994, и Народно позориште Републике Српске од 1994. године) и три управника: Петар Павић (1990-1992), Небојша Зубовић (1992-1994) и Љиљана Лабовић (1994-1998). Петар Павић је „раскрстио“ са придјевом босанско, Зубовић је управљао крајишким, док је Лабовићка промовисала и утемељила Народно позориште Републике Српске. Процес честих промјена имена Народног позоришта открива nутағы јединог професионалног позоришта у Републици Српској и њен културни и национални идентитет.

Петар Павић је унук Петра Кочића, а „прст судбине“ удесио је да баш Он - 1990. године, путем конкурса - дође из Београда и преузме дужност првог ратног управника ове позоришне куће. На почетку управникована дочекао га је, упереног прста, бронзани деда, а на крају је његовом 
заслугом и ангажовањем редитеља Петра Зеца, послије педесет година, у хол Позоришта враћено попрсје оснивача и мецене овог значајног здања: краља Петра Првог Карађорђевића. У јесен исте године, други Павић, Јовица, редитељ југословенске и међународне репутације, долази у Бању Луку заједно са Милорадом Телебаком (лектор и умјетнички директор Позоришта), а њихове двије представе: Семе Мирољуба Недовића (19. 10. 1992) и Бенерал Милан Недић (16. 4. 1993) представљају прекретницу у репертоарској политици националног позоришта Републике Српске (SIMOVIĆ 2011: 17).

На тој линији развијала се и репертоарска политика Љиљане Лабовић, гдје се као стајна мјеста издвајају представе Прини Растко - Монах Сава Милована Витезовића - 27. јануар 1995. (Велика сцена) и Емигранти Славомира Мрожека - 7. јун 1995. (новоотворена Мала сцена). Прва указује на основне етичке оквире православне - светосавске духовности, док друга, у својеврсној посрби Бранка Брђанина Бајовића, отвара питања идентитета, избјеглиштва и отуђења, као сижејних оквира који ће, на дуже, обиљежити драмско стваралаштво у Републици Српској и земљама окружења.

Нешто раније, враћајући се привидно на мелодрамске изворе Шантића и Ћоровића, појављује се рукописна драма Бранка Брђанина Бајовића Пада киша... јагодо (2011:183-219).

Објављена је десетак година након свог настанка, а до сада није извођена, иако су њена драмска композиција, избор сценског простора, број ликова, промјене сцена као и друге позоришне захтјевности - намјенски прилагођени сиенском минимализму ратних (не)услова. Драма је уоквирена у пролошку и епилошку сцену гдје се актуелизује проблем забрањене лубави босанског Ромеа и Јулије, која се преко кастинске нетрпељивости и грађанског рата сурвава у апсурдну фарсу. Архетипски мотив забранене љубави Брђанин је хронотопски преселио „негдје у Босну“, на провинцијску позорницу - чекаоницу аутобуса, и временски ужљебио и згуснуо у сами почетак грађанског рата у Босни и Херцеговини. Прве сцене, а има их пет, сажимају стање бесловесности, односно једну посве неразумну ситуацију у којој сви актери драме осјећају како се нешто страшно спрема, а нико ништа не чини да се од тог страшног измакне, помјери или заштити. Наиме, заљубљени пар, босански Ромео и Јулија, Божо и Алма, хистерично убрзавају синхронијску композицију драме, несвјесни да ће њихов будући брак ланчано отворити дијахронију ратне пропасти која овај драматуршки стереотип из мелодрамске безбрижности преображава у ратну трагедију.

Брђанин је, поред наведене посрбе Емиграната и прве ратне драме Пада киша... јагодо, осмислио и прву селекцију фестивала Кочи- 
ћева српска сцена у Приједору који ће, у годинама трајања - од 1994. до 2007 - остварити пресудан утицај на развој драмског стваралаштва у Републици Српској. Оно што је учинио Јовица Павић за Народно позориште Републике Српске, у истој је мјери учинила и Кочићева српска сцена за развој њеног позоришног живота. Послије првог Фестивала почела су да се буде многа мала - камерна позоришта у Љубињу, Обудовцу, Требињу, Власеници, Милићима, Зворнику, Бијељини, Лукавици, Касиндолу, Градишци, Брчком, Бањој Луци и другим мјестима. Фестивал је посебно утицао на репертоарску политику Позоришта у Приједору гдје се све више изводи савремена српска драма. Од аутора из Републике Српске посебно су занимљиве двије праизведбе које су реализоване на самом крају позоришне сезоне двадесетог вијека. Ради се о праизведби монодраме Кома Зорана Костића у режији Раденка Билбије, и драмском тексту Рада Симовића Хамлет у Рајској долини Српске који је режирао Миодраг Мага Милановић (2011: 271-323).

Афирмација домаћих драмских писаца и позоришни повратак Петру Кочићу могао би да се издвоји као програмски приоритет Народног позоришта Републике Српске на крају двадесетог и почетком двадесет и првог вијека. Доласком Жељка Стјепановића на мјесто директора Народног позоришта (1998-2004) адаптирана је и отворена Мала сцена, која је понијела име Петра Кочића. Свечано отварање уприличено је 5. априла 2004. године и то премијером представе Петар Кочић аутора Гојка Бановића, у драматизацији Жељка Стјепановића и режији Јовице Павића. Отварањем нове сцене, Позориште је отворило врата младим драмским писцима, гдје се у новом драмском изразу издвојила Радмила Смиљанић са првом драмом, дипломским радом, одбрањеним на одсјеку драматургије бањолучке Академије умјетности (SIMOVIĆ 2011: 40).

Праизведба представе Радмиле Смиљанић Балон од камена уприличена је у Народном позоришту, 3. маја 2009. године (PROGRAMSKA KNJIŽICA 2009: 8). Она је уједно означила појаву нове драме у којој се преко театрализације егзистенцијалне збиље и поетске имагинације утемељују шири и сложенији оквири драмског стваралаштва у Републици Српској.

Радмила Смиљанић структурише ову драму као низ реалистичких призора из Слободанкиног дјетињства. Али ове призоре, у занимљивом драматуршком поступку који осмишљава Радмила Смиљанић, прате коментари исписани у дидаскалијама текста. Коментари, исписани у форми малих прозних цјелина, имају квалитет монолошких елемената кроз које се одвија једна паралелна радња драме. Осим што је драгоцјена са становишта усложњавања значења текста, ова оригинална драмска техника омогућава и да се успостави једна комплексна временска пер- 
спектива: хронолошки приказ приче о Малој Слободанки, релативизован је погледом „из будуће“, већ испуњене, завршне радње. У овом сасвим оригиналном драмском поступку очитује се и познавање савремених драматуршких техника, насљеђа модерне драме деведесетих година прошлог вијека, од Мартина Кримпа и Саре Кејн, до Марка Рајвенхила, Фон Мајенбурга и водећих писаца сада актуелне драматургије. Међутим, Радмила Смиљанић своје познавање савремених драмских пракси не примјењује директно. Код ње нема обавезних постдрамских „изума“ она искуство познавања постдрамског театра користи прије свега да на многим мјестима драму растерети сувишног вербалног материјала и да створи услове да се призори одвијају кроз компоненте сценског језика. Зато неке од слика из њене драме дјелују толико пластично већ на нивоу текста, да је лако замислити њихов будући изглед. Тај изглед уприличила су изузетна редитељска рјешења Филипа Гринвалда у наведеној представи Народног позоришта Републике Српске. Представа се, избором селектора, такмичила на XXVI Cусретима позоришта/казалишта БиX у Брчком 2009. и Фестивалу босанскохериеговачке драме у Зеници - 2010. године. На оба фестивала Балон од камена Радмиле Смиљанић, одлуком стручног жирија, освојио је награду за најбољи савремени (оригинални) драмски текст (2011: 42).

У вријеме кад је Радмила Смиљанић награђена за најбољи савремени босанскохериеговачки текст који је изведен на Фестивалу у Зеници, у новосадском Часопису за позоришну уметност „Сцена“ објављен је драмски првенац Тање Шљивар Пошто је naumema? (ŠLJIVAR 2010: 164-180), младе бањолучке списатељице, тадашњег апсолвента драматургије на Факултету драмских умјетности у Београду.

Гледано из контекста наших драмских продужетака Тања је имала свега пет година кад су заметане прве ратне драме, а ако изнова призовемо (парафразирамо) егзистенцијалисте и њено дјетињство је обиљежила несрећа (као и Малу и Велику Слободанку.) Не чуди, онда, што је драматуршка потка основана и саздана на „документарним детаљима“ гдје са лакоћом препознајемо Маглајане код Лакташа, причу о Славици Радић, касније Еклстон, Ди џеј Крмка и месара Стојана, који, сами по себи не значе ништа све док „документарни детаљи“ не почну да „лебде“ и снагом списатељске имагинације умреже и обликују драмско ткиво метафоричког назива Пошто је naumema?

Београдско позориште Ателе 212 овај је комад одмах препознало и прихватило, праизведба је одиграна 15. јануара 2012. године на 
сцени Театра у подруму у режији Снежане Тришић, и са Зијахом Соколовићем као тумачем главне улоге. Недуго затим, драма је одиграна у Народном позоришту Републике Српске, у званичној селекцији петнаестог фестивала Театар фест Петар Кочић. Интересовање публике било је изненађујуће, прибјегло се двоструком извођењу, а све остало, од округлог стола до медијске перцепције, дјеловало је млакасто. Катарзу драме није приредила представа, већ фестивалски жири, наградивши на крају Фестивала драмски предложак Мрзим истину Оливера Фрљића наградом за најболи драмски текст Фестивала (TEATAR FEST 2018: 196).

Вратимо се објављеној драми која синхронијски, правилним рукописом колажне драматургије компонује и у цијелости онеобччава простор и јунаке а посебно однос јунака и судбине Месара Стојана. Месара Лој у Маглајанима центар је оновременог и ововременог свијета у којој се рађају нови Стојани, коље, крчми и транжира, једе живо месо, све док се не појави голо женско тијело Славице Радић, будуће манекенке. Она долази зато што одлази, жели да се опрости јер је намјерила да потражи срећу у Јапану, земљи вјечно излазећег сунца. Стојан пипа голо женско тијело савршеног склада први пут и на њему у драматуршком сплету дрхтавих асоцијација проналази цијело једно животиғско иарство божанског провиђења. Људско осјећање, у додиру са божанским исконом, заметнуло је Стојанову идеју о изградњи будистичког храма у коме ће живјети он и Славица и рађати нове Стојане. Десио се, дакле, драмски преображај достојан античког свијета - до краја необичан у својој обичности. Овдје и буквално Субјекат жели Објекат, Стојан безусловно започиње и гради будистички Храм, тик уз православну Цркву (љубав је ипак могућа!) упркос рату, рекетирању и „јуначким“ Противницима састављеним од ратног „шкарта“ преосталих комшија и пријатеља. У тој и таквој подјели „помаже“ му једино естрадни умјетник Ди-џеј Крмак, који тезгари у дискотекама водећих европских градова и повремено одмара у месари/кафани Лој. Он је динамички покретач радње, помоћникпротивник, тужни поштар и проводаџија који доноси кључну вијест да је Славица постала госпођа Еклстон. И то је вршна тачка драматуршке композиције. Након тога, у наглом паду, Ди-џеј Крмак „испроси“ ветеринарку Јованку која се одмах након свадбе прихвата месарске сатаре. Храм ће убудуће служити за снимање телевизијских спотова док ће душу Стојанову умјесто вјечно излазећег сунца и даље обасјавати боја меса и мрклина крви. Наставиће да кида комадиће мозга и жваће их, док не почне да повраћа, не престајући да једе мозак, а потом ће да мало кркља на поду, па умире.

Да поједноставимо, Стојан је живи леш у утроби брода а на преображај и васкрснуће његовог лика и дјела у Републици Српској неће се 
дуго чекати.

Активитет и агоналност свих досадашњих драма може да се сажме и сабије у трагички ритам глувог гламочког кола које парадигматски обједињује игру, народно глумовање и привидну саборност одабраних. Онај ко вуче коло на своју страну за остале је шкарт, а они га избаиуjу из кола и настављају да играју. Избачени саиграч навлачи рукавиие и напушта коло, улази у свијет Шалтера, на прву линију позадине, једну врсту ововременог Чистилишта у коме се искушавају и припремају душе отпадника за блаженство Раја. Са овом и оваквом дидаскалијом, препричаном нашим очима, Марио Ћулум, професор драматургије на бањолучкој Академији умјетности, отвара врата драмског првенца Шалтер (2013: 194-210) у коме се, у свега неколико реченица, премоштава развојна линија европског позоришта: од ритуално-магијског до апсурдно-антидрамског.

Драма баштини насљеђе драматуршки уског хронотопа изабраних драма у који се увлачи нихилистичка постојаност оних који чекају: пензионерке, мајке, неудате, инвалида, дјевојчиие, срећно удате, бизнисмена, певачице и мушкария - привидно живих актера Ћулумове драме. Они чекају и клече испред Службеника који се први уздигао до узвишене празнине одрицана, сви су једнако безимени а само је он први, и сви се једнако отимају око крвавог дисплејског броја $(1914,1941,1968,1974$, 1995), односно Тачке историјског идентитета у којој су погубљена њихова имена и презимена. Привидно живи људи Марија Ћулума довршили су недовршену драму Алексе Шантића Пред капијама Светог Петра. Ради се о историјски недореченој речености наших дана које су појели скакавии узалудно обијајући сопствене животе и (бјело)свјетске шалтере. Зато се, у драматуршком поретку Републике Српске, Ћулумов Свети Петар самоодрекао правичности и преобликовао у Службеника (он је једини идентитетски постојан, у сваком тренутку зна шта хоће и шта тражи, а хоће мито) и пред себе извео бекетовске агоналие који се отимају око ирвено-крвавих бројева шалтерског приоритета. Успут се забављају ироничним подбадањима, халапљивим једењем бомбона, и илегалним опијањем. Посебно Мајка, једина стварна и будућа родиља неких нових чекалаца. Остало је успутно, може и не мора, од срећно удате жене, бизнисмена и певачице који су више у функцији драмске радње и питања како се она одвија него зашто се тако саплиће.

О томе како је „у драми“ понешто је већ речено на њеној праизведби у Народном позоришту Републике Српске, 26. фебруара 2013. године, док питање зашто је то тако и даље „виси“ над овим текстом (PROGRAMSKA KNJIŽICA 2013: 8). Оно се може исказати чињеницом да актер Инвалида није до краја реализован иако је метафорички доведен 
до крајњег стадијума удвојене личности, као и актер Дјевојчице која се драматуршки погубила, и поред чињенице да на почетку комада узима и гута пилуле за срећу које би, током драме, требало да прерасту у таблете за несрећу.

Мотив чуда и топоним кафане трајно је обиљежио свјетску драматургију и радикално трансформисао српску - присјетимо се само Чуда y Шаргану Љубомира Симовића и све нам се појашњава. Мотив је стајан и у босанскохерцеговачкој драматургији: од Алије Наметка и његовог Абдулах-паше у касаби до Чуда у Латинлуку Џевада Карахасана. Од свих чекаонииа кафана је најчешћи хронотоп и логичан избор Јелене Којовић Тепић да причу сарајевских српских избјеглица смјести и удоми Код вјечите славине (2014, стр. 119-147). Ради се о побједничком драмском тексту са трећег конкурса за драмски првенаи Београдског драмског позоришта. Прича се прво посрећила а потом се, како то обично бива, закомпликовала. Београдско драмско позориште нагло је одустало од награђеног првенчета а текст је преузело Народно позориште Републике Српске. (У позоришту се никада не зна када ће лоши потези испасти добри а добри лоши.) Драма је прво објављена у Часопису за позориште и визуелне комуникације „Агон“, а праизведба је одиграна на Сцени Петар Кочић Народног позоришта Републике Српске, половином децембра 2015. године. Режију је потписао Игор Тешић, драматуршке интервенције приредио је Милан Гајић, у тачној и добро укомпонованој глумачкој подјели: Слађана Зрнић, Смиљана Маринковић, Ђорђе Марковић, Горан Јокић и Горан Колопић (PROGRAMSKA KNJIŽICA 2015: 10).

Назив драме упућује на цитатну релацију са Момчилом Настасијевићем која је прихватљива у дубинским аналогијама док би се драматуршко насљеђе прије могло потражити код Алексе Шантића и Светозара Ћоровића. Ратно и постдејтонско Сарајево велики је изазов за српске ствараоце у Босни и Херцеговини и немали је број пјесника, прозаиста и филмских документариста који су на овој теми изградили препознатљива умјетничка свједочења. Колико је нама познато егзодус сарајевских Срба, као најболнија тема новије српске историје, једино је ваљано обрађен у српској поезији и документарном филму Крстић. Прозна литература и драмско стваралаштво и даље траже писиа на скученом хоризонту очекивања.

Наш је утисак да је драма Јелене Којовић Тепић отресито обновила вјечну тему и вишеструко најавила њене продужетке. Нимало случајно, јер је и Јеленино дјетињство, попут Радмиле Смиљанић и Тање Шљивар, обиљежила несрећа. Избјегличка драма сарајевских Срба смјештена је ту негдје у околини Бање Луке, у периферној кафани гдје јунаци живе и преживљавају избјегличку трагедију. А све дјелује као да се Балон 
од камена коначно усидрио у Маглајанима и додатно скућио код Месара Стојана.

У првој равни драме кључни је актер Момчило Ђурић, газда кафане, одан алхохолу и својим кћеркама, некадашњи доктор историјских наука и угледни грађанин Сарајева. Причу отвара Нада која ишчекује млађу сестру Раду, узданицу и једину сламку спаса ратом испошћене и растурене породице. Рада је дипломирани менаџер и будући постдипломац Мегатренда (добила је изненадног спонзора и стипендију!), опсједнута темом малих пословних ијелина у неразвијеним опитинама. Њена је намјера да подигне ниво послована прво у породичној кафани а потом и даље - све до Бање Луке.

У пролошкој измјени Шофера заљубљеног у Наду и Мијановића, власника ланца месара, долази се, изненада, до првог драмског препознаваға гдје Рада сазнаје да је Мијановић њен будући Спонзор. Композицију убрзава и усложњава повратак Шофера, власника једног камиона и црног Гаврана, тако да се мелодрама заокружује и у овој фази до краја попуњава. Остало је да се погађамо око расплета са срећним крајем. Добро скројен комад употребљив и уприличен као утјешна награда за све избјегле, прогнане и унакажене сарајевске Србе. Може и тако, да се не ради о ауторки озбиљног животног и читалачког искуства, набиљеженог ратом, избјеглиштвом, и свом муком овога свијета концентрисаном у егзодус Срба и спонзорске манипулације домаћих и свјетских профитера. У магли кафане и магми алхохолних испарења нагло се подиже и тензија комада, драматуршки испливава леш у утроби брода, тајна мајчине смрти, која сурово открива да је Мијановић Радин стварни отац, месар/ љубавник, који је прво уништио избјегличку породицу а сад је спасава крвавим новчаницама. Одлучан у намјери да прихвати Раду, своје биолошко дијете, једини спас и наду Момчила Ђурића. Овим се мелодрамски драмски оквири разобручују а јунаци успињу до трагичких висина. Доскорашње препознаваюе саображава се у самоспознаване и прелама на судбини најмлађег дјетета. Рада постаје хероина колективне несреће, прихвата улогу јунака трагедије и нагло се враћа у Србију. Ибзеновски залупљена врата унутар сладуњаве композиције нагло су и неочекивано изюедрила грађанску трагедију. За крај је остављена шачиияа трагичког поспремања, Нада се удаје за Шофера док пијани отац, слутимо, изговара посљедњу реченицу: ти ћеш мени да кажеш кад је фајронт у мојој кафани; док одзвања празнина и катарзично питање - да ли је мајка извршила самоубиство или је убијена?

Процес самоодрицаюа довршен је у Шалтеру Марија Ћулума, док је чин уништавана и самоуништавана прогнаника поново отворен. Сликом поцијепаног оца поцијепане породице у новој сарајевској крвавој 
кошуль локалних клаоница. У праву је Сиоран, истина боли!

\section{Цитирана литература}

BILTEN 2018: XXXV Susreti pozorišta/kazališta. Bilten br. 8. Brčko: Vlada Brčko distrikta BiH, 2018. [orig.] Билтен (2018). XXXV Сусрети позоришта/ казалишта. Билтен бр. 8. Брчко: Влада Брчко дистрикта БиХ, 2018.

ĆUlUM 2013: Ćulum, M. „Šalter“. Scena, br. 1, 2013, 194-210. [orig.] Ћулум, М. „Шалтер“. Сцена, бр. 1, 2013, 194-210.

KOJOVIĆ TEPIĆ 2014: Kojović Tepić, J. Kod vječite slavine. Agon, br. 4, 2014, 119147. [orig.] Којовић Тепић, J. Код вјечите славине. Агон, бр. 4, 119-147.

PROGRAMSKA KNJIŽICA 2009: Programska knjižica. Balon od kamena. Banja Luka: Narodno pozorište Republike Srpske, 2009. [orig.] Програмска књижица. Балон од камена. Бања Лука: Народно позориште Републике Српске, 2009.

PROGRAMSKA KNJIŽICA 2013: Programska knjižica. Šalter. Banja Luka: Narodno pozorište Republike Srpske, 2013. [orig.] Програмска књижица. Шалтер. Бања Лука: Народно позориште Републике Српске, 2013.

PROGRAMSKA KNJIŽICA 2013: Programska knjižica. Istina (ne) boli. Banja Luka: Narodno pozorište Republike Srpske, 2015. [orig.] Програмска књижица. Истина (не) боли. Бања Лука: Народно позориште Републике Српске, 2015.

SIMOVIĆ 2011: Simović, R. Drama i identitet. Banja Luka: Art print, 2011. [orig.] Симовић, Р. Драма и идентитет. Бања Лука: Арт принт, 2011.

SIMOVIĆ 2011: Simović, R. Drama Republike Srpske. Banja Luka: Art print, 2011. [orig.] Симовић, Р. Драма Републике Српске. Бања Лука: Арт принт, 2011.

STJEPANOVIĆ 2018. Stjepanović, Ž. Naši dani. Banja Luka: Arhiv Narodnog pozorišta Republike Srpske, 2018. [orig.] Стјепановић, Ж. Наши дани. Бања Лука: Архив Народног позоришта Републике Српске, 2018.

ŠLJIVAR 2010: Šljivar, T. „Pošto je pašteta?“ Scena, br. 3, 2010, 164-180. [orig.] Шљивар, Т. (2010). Пошто је паштета?. Сцена, бр. 3, 164-180.

TEATAR FEST 2018: Teatar Fest Petar Kočić - pregled dosadašnjih festivala, 2018. [orig.] Театар Фест Петар Кочић - преглед досадашних фестивала, 2018 . 
Rade Simović

\section{CONTEMPORARY AND NEW DRAMA OF THE REPUBLIC OF SRPSKA}

The aim of this paper is to offer a sort of "short review" of the representative dramas of the Republic of Srpska and to analyse the "concrete chronotope" of the Serbian dramatic art in Bosnia and Herzegovina. The author tried to show the development of the theatre life of the Republic of Srpska. It leads to the conclusion that the "story" about the contemporary theatre of the Republic of Srpska and about its less known authors deserves some more thourough academic approach.

Keywords: Serbian drama, context, dramaturgical composition, melodrama, historical drama, post-dramatic theater 